\title{
DYNAMICS OF DEVELOPMENT OF FINANCIAL SAFETY OF THE ENTERPRISE AS A COMPLEX ECONOMIC SECURITY OF THE STATE
}

\author{
Tetiana GANUSHCHAK ${ }^{1}$ \\ Kyiv National University of Trade and Economics, Ukraine
}

\begin{abstract}
The purpose of the paper is to the performance of the evaluation of the financial safety of the enterprise. To achieve the stated aim it has been necessary to solve the following tasks: to use the approaches as to the evaluation of the financial safety of the enterprise, to introduce the analysis system of the financial safety of the enterprise, to consider the structural logical scheme of the analysis procedure of the financial safety of the enterprise, to give the description of the integral indicator of the financial safety of the enterprise; to evaluate and compare companies in the paltry industry according to the level of their financial safety. Methodology. Methodologial basis of the research are the scientific methods, such as : method of logical generalization, dialectical method of recognition of the economic phenomena - to give the definitions of «economic security of the enterprise», "financial security of the enterprise», grouping method, analysis which were used to estimate indicator position of the financial security of the poultry company, graph method which was applied to compare integral estimation of the enterprise;methods of synthesis, deduction, induction, method of the expert estimation to calculate and implement integral marker of the financial security of the poultry company;method of the correlation analysis which was used to identify weight coefficients of the all sided figures of the solvency, business activity, profitability, financial steadiness, pay ability. The priority in methods using was defined by the particular tasks and goals. Results of the research showned into a wide set of the ways of financial enterprise safety as a component of economic security of the state. There is an evaluation of enterprise financial safety on the basis of calculations of integral indicator, including combined indices of profitability (unprofitability), pay ability or the lack of that, business activity (fading), financial steadiness (unsteadiness), efficiency (inefficiency) of the property state. Finally, the given work presents the system of financial safety of the enterprises, including the agents of financial security and subsystems of management to provide financial safety of the enterprises. Practical implications. The given methodology of the integral estimation of the enterprise financial security on the basis of all sided markers of the profitability, financial steadiness, business activity has been implemented successfully into production Joint Venue 'Kyiv Poultry Farm'. Value/originality calculations are done on the basis of the introduction of the personal formula of the integral estimation of the financial security of the enterprise as a component of economic security of the state
\end{abstract}

Key words: enterprise, definition, scheme, financial safety, integral indicator, economic security of the state, profitableness, solvency, business activity, financial steadiness.

JEL Classification: G3, Q1

\section{Introduction}

Financial safety of the enterprise as a component of economic security of the state must be formed and put into operation on the basis of solving the problems, connected with multi factors which enable to control and foresee the modern surrounding for functioning the system of the financial safety of the enterprise. They are also connected with comparison of the dynamics of changes, diagnosis of the state, fast adaptation and taking decisions as to management depending on the spheres of the activity. The main issues in the paltry industry is the absence of the unified method of the evaluation of the financial safety, the unified approach as to the management of the mechanism of the provision of the enterprise financial safety, the authority realization and their deputies and top-managers their insufficient acknowledgement ; the unified mechanism of financial safety evaluation, created on the basis of the research about the peculiarities of the industry; taking into consideration the individuality of a separate firm or company; targeting the customers. The problem of the evaluation of the financial safety as a component 
of economic security of the state has been burning nowadays.

\section{The lay out of the contents and giving grounds of the research results}

From the angle of economic targets there are different points of view at to the 'security', that is the proper 'enterprise economic (Table 1).

Economical safety is the core function of the enterprise activity to avoid the destructive processes. (Bolbotenko, 2012) One of the main parts of the economical safety is financial safety of the enterprise.

Let us investigate the approaches as to evaluation of the financial safety of the enterprise (Table 2).

Look at the structural logical scheme of the procedure of the analysis of the financial safety of the enterprise (Figure 1).

Let us look in to the formula of the integral estimation of the financial safety of the enterprise which was calculated by experimental way and looks the following: (Ganushchak, 2012)

$$
\begin{aligned}
& \mathrm{SFSE}=0,42 \mathrm{SR}+0,49 \mathrm{SP}+0,8 \mathrm{SBA}+ \\
& +0,43 \mathrm{SFS}+0,38 \mathrm{SPS}
\end{aligned}
$$

where SFS - integral indicator of the financial safety (insafety) of the enterprise;

SR - combined indicator of the profitableness (unprofitableness) estimation ;

SP - combined indicator of the solvency (insolvency) estimation;

SBA - combined indicator of the estimation of the business activity (fading);

SFS - combined indicator of the estimation of the financial steadiness

(unsteadiness);

SPS - combined indicator of the effectiveness (ineffectiveness) of the property state.

By means of the expert estimation there have been established norm meanings of the integral indicator of the financial safety of the enterprise, as the following:

(-5 Ao 0$]$ - the dangerous financial state of the enterprise;

[from 0 to 1 ] - provision of the low level of the financial safety of the enterprise;

[from 1 to 5] - provision of the middle level of the financial safety of the enterprise;

[5 and higher] - provision of the high level of the financial safety of the financial safety of the enterprise.

Table 1

Approaches to the meaning 'enterprise economic security'

\begin{tabular}{|l|l|}
\hline \multicolumn{1}{|c|}{ Author } & \multicolumn{1}{c|}{ Approach } \\
\hline $\begin{array}{l}\text { Kopitko N.I. } \\
\text { (Kopitko, 2015) }\end{array}$ & $\begin{array}{l}\text { The complex of means in the system of economic activity aiming the adaptation of the subjects of the social- } \\
\text { economical relationships towards to changeable outer surrounding, defending the enterprise benefits, preventing inner } \\
\text { and outer threats and to using the possibilities with maximum results }\end{array}$ \\
\hline $\begin{array}{l}\text { Alkema V.G. } \\
\text { (Alkema) }\end{array}$ & $\begin{array}{l}\text { Notion involving many aspects to reflect the certain state and possibilities of the system object. The system of } \\
\text { economic security - is the core function of the system which is realized due to a certain collection of the subsystems } \\
\text { and elements.The system of the economic security under globalization conditions is complex open hieratic many } \\
\text { leveled economic system. }\end{array}$ \\
\hline Author's approach & $\begin{array}{l}\text { It's a complex of economic relations which exist to provide with constant well balanced interests of the enterprise and } \\
\text { the state considering inner and outer factors of the influence and floating time. }\end{array}$ \\
\hline
\end{tabular}

Table 2

The approaches to the definition 'evaluation of the financial safety of the enterprise'

\begin{tabular}{|c|l|c|}
\hline Author & \multicolumn{1}{c|}{ Approach } \\
\hline $\begin{array}{c}\text { O.V. Nusinova } \\
\text { Nusinova, 2011) } \\
\text { of the capital value by means of dividend payment to the investors. If the dividend payments are equal or exceeds } \\
\text { economical amortization then there is no lowering of the financial safety. If the economical amortization exceeds the } \\
\text { sums of dividend payments then there appears debts with owners, which must be taken into consideration while } \\
\text { calculate the initial business value on the basis of which the level of the financial safety is defined. }\end{array}$ \\
\hline $\begin{array}{c}\text { Biloshkurska N.V. } \\
\text { (Biloshkurska, }\end{array}$ & $\begin{array}{l}\text { The author suggest evaluating financial economical safety of the enterprise on the basis of the indicator including } \\
\text { coefficient of the fund return of the fixed capital, coefficient of the labour productivity, coefficient of the capital-labor ratio } \\
\text { coefficient return material coefficient working inventory turnover, coefficient depreciation }\end{array}$ \\
\hline $\begin{array}{c}\text { Khrapkina V.V. } \\
\text { (Khrapkina,2010) }\end{array}$ & $\begin{array}{l}\text { The author suggests undertaking the evaluation of the current rate of the financial safety according to the following } \\
\text { approaches of the analysis: analysis of the financial reports of the enterprise within its financial manufactory activity, } \\
\text { which includes enterprises structure capital analysis, liquidity which includes the analysis of the capital structure of } \\
\text { the enterprise, analysis of its pay ability and financial steadiness , the analysis of the expenses, the analysis of the profits } \\
\text { and debts, the analysis of the competitive advantages and comparative analysis as to the competitive, the analysis of the } \\
\text { assortment of the products, the analysis of the level and quality of the enterprise management. }\end{array}$ \\
\hline $\begin{array}{c}\text { I.I. Bilomistna } \\
\text { (Bilomistna, 2014) }\end{array}$ & $\begin{array}{l}\text { The author states that it is a complex process, which includes not only the indicators to make the analysis, but the range } \\
\text { of the boundaries in the limits of which the cert in indicator has to be. }\end{array}$ \\
\hline
\end{tabular}




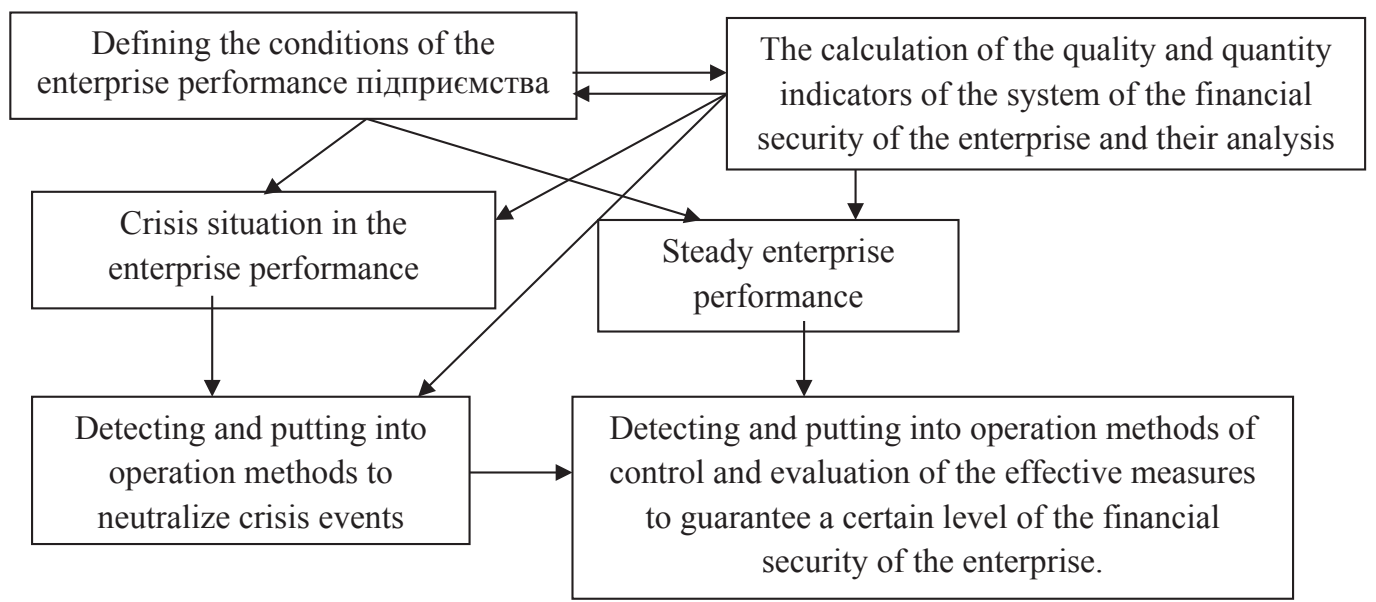

Figure. 1. Structural logical scheme of the procedure of the analysis of the financial safety of the enterprise The source: (Petryna, 2010)

Let's look into dynamics. Integral indicator of the financial safety of the JSC 'Plemptakhodadgosp Brovarskiy'in the years of 2008-2016. (Figure 2).

According to Figure 2 it is seen that the integral marker of the enterprise financial security in 2009 as to compare with the year 2012 tended to grow lower, in 2014 the given indicator grew up. In 2010 the indicator grows up, while from 2010 till 2012 the indicator became smaller.

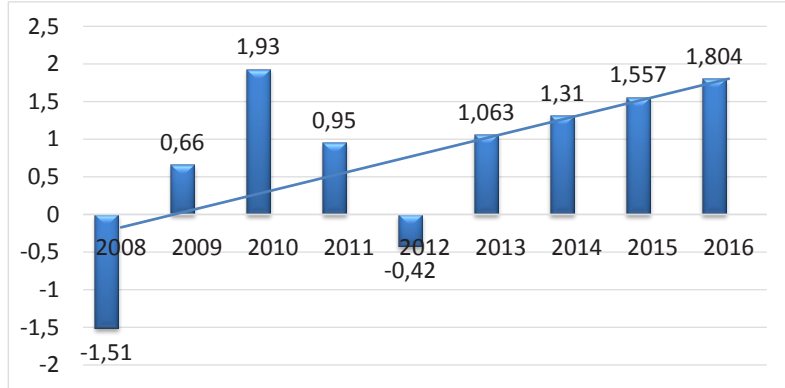

Figure 2. Integral indicator of the financial safety of the JSC 'Plemptakhodadgosp Brovarskiy'in the years of 2008-2016

The source: worked out by the author on the basis of the National commission of the Securities and Stock Market data (Ukrainian enterprise reports)

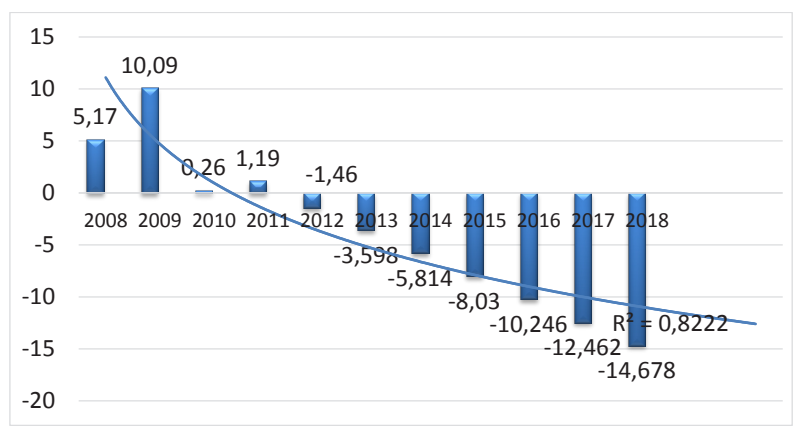

Figure 3. Integral indicator of the financial safety of the JSC of theVasylkivska Poultry Farmin 2008-2016

The source: worked out by the author on the basis of the National commission of the Securities and Stock Market data (Ukrainian enterprise reports)
From 2013 to 2016 there is an increase in the indicator.

Let's see the dynamics. Integral indicator of the financial safety of the JSC of theVasylkivska Poultry Farmin 2008-2016. (Figure 3).

According to Figure 3 Integral indicator of the financial safety of the JSC of the Vasylkivska Poultry Farming 2008-2016 it is seen that the this indicator since 2012 to 2016 was negative and in the year of 2016. In 2018, it is also expected to reduce this indicator.

Let's see the dynamics. Integral indicator of the financial safety of the JSC 'Kyivska Poultry Farm' in the years of 2008-2016. (Figure 4).

According to Figure 4. Integral indicator of the financial safety of the JSC of 'Kyivska Poultry Farm' in the years of 2008-2016. In 2009, 2010 and 2012 there was a slight fluctuation in production. From 2013 to 2016 this indicator tended to decrease.

Let's see the dynamics. Integral indicator of the financial safety of the JSC 'Krushynsky Paultry Complex' in the years of 2008-2016. (Figure 5).

According Figure 5 Integral indicator of the financial safety of the JSC of 'Krushynsky Poultry Complex' in the years of 2008-2016. In 2008, compared with

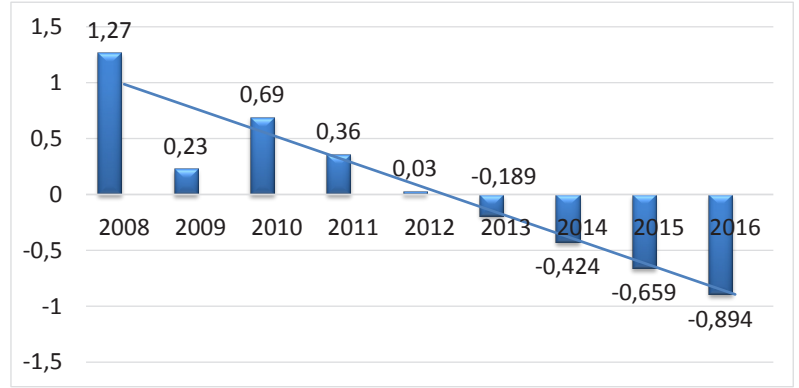

Figure 4. Integral indicator of the financial safety of the JSC of 'Kyivska Poultry Farm' in the years of 2008-2016

The source: worked out by the author on the basis of the National commission of the Securities and Stock Market data (Ukrainian enterprise reports) 


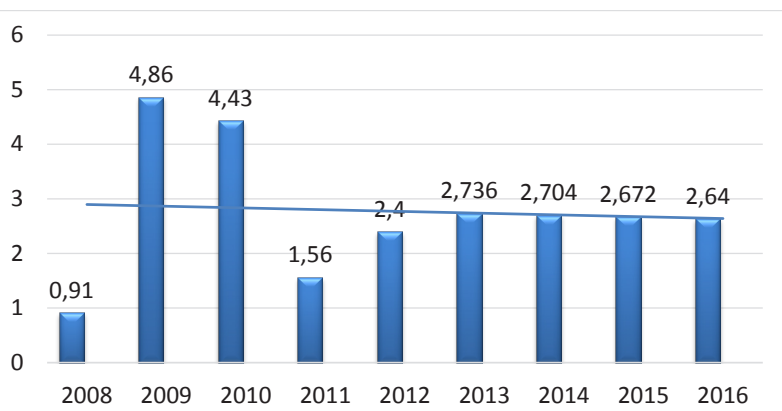

Figure 5. Integral indicator of the financial safety of the JSC of 'Krushynsky Paultry Complex' in the years of 2008-2016

The source: worked out by the author on the basis of the National commission of the Securities and Stock Market data (Ukrainian enterprise reports)

2009, financial security of the company grew. In 2011, compared with 2010, decreased. The positive dynamics was in 2012 and 2013.

Let's see the dynamics. Integral indicator of the financial safety of the JSC “Ukraina Poultry Farm' in 2008-2016 (Figure 6).

According to Figure 6 Integral indicator of the financial safety of the JSC of "Ukraina Poultry Farm' in 20082016. There was a dramatic shortage of production in 2009 and 2010. From 2013 to 2016 there is an increase in this indicator. Also, it is projected that in 2017 and 2018 there will be an increase in the integral index of financial security of the enterprise.

To concordance the calculations of the integral indicator of the financial safety of the enterprise in this economical branch can be presented in the following table.

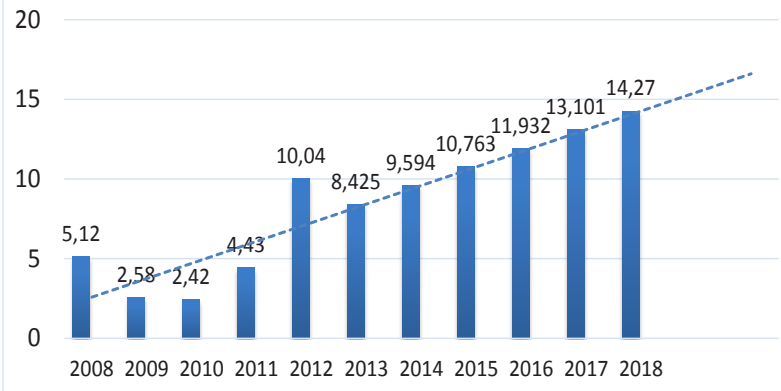

Figure 6. Integral indicator of the financial safety of the JSC of “Ukraina Poultry Farm' in 2008-2016

The source: worked out by the author on the basis of the National commission of the Securities and Stock Market data (Ukrainian enterprise reports)

Having considered table 3 data it is clear to see that the lowest integral indicator of the financial safety in 2010-2012 in JSC «Vasylkivska Poultry Farm' and it made up -4,97; -4,26; -2,01; -1,97; 0,26; $-1,46$ respectively, in 2008 JSC 'Plemptakhodadgosp Brovarskiy'», that is $-1,51$, in 2009 p. and 2015 p. 0,$23 ; 0,36$ respectively. The highest indicator of the financial safety was in JSC 'Krushynsky Poultry Complex' in 2010 and it made up 10,01; 9,12; 6,88; 4,43 respectively, in 2008-2012 JSC Vasylkivska Poultry Farm' that is 5,17; 10,09 respectively, in 2015-2016 JSC Ukraina Poultry Farm', that is : 10,$763 ; 11,932$ respectively.

Having considered table 4 data it is clear to see that the 1st place in the financial safety in the years of 2008, 2009 was in JSC 'Krushynsky Paultry Complex'; in 20112016 was in JSC Ukraina Poultry Farm', 2010 was in

Table 3

Grouped integral indicator of the financial safety in several enterprises of the Poultry industry in the years of 2008-2016

\begin{tabular}{|l|c|c|c|c|c|c|c|c|c|}
\hline \multicolumn{1}{|c|}{ Enterprise } & \multicolumn{9}{c|}{ Years } \\
\cline { 2 - 11 } & 2008 & 2009 & 2010 & 2011 & 2012 & 2013 & 2014 & 2015 & 2016 \\
\hline 'Plemptakhodadgosp Brovarskiy' & $-1,51$ & 0,66 & 1,93 & 0,95 & $-0,42$ & 1,063 & 1,31 & 1,557 & 1,804 \\
\hline 'Vasylkivska Poultry Farm' & 5,17 & 10,09 & 0,26 & 1,19 & 1,46 & $-3,59$ & $-5,81$ & $-8,003$ & $-10,24$ \\
\hline 'Kyivska Poultry Farm' & 1,27 & 0,23 & 0,69 & 0,36 & 0,03 & $-0,189$ & $-0,424$ & $-0,659$ & $-0,894$ \\
\hline 'Krushynsky Paultry Complex' & 0,91 & 4,86 & 4,43 & 1,56 & 2,4 & 2,736 & 2,704 & 2,672 & 2,64 \\
\hline 'Ukraina Poultry Farm' & 5,12 & 2,58 & 2,42 & 4,43 & 10,04 & 8,425 & 9,594 & 10,763 & 11,932 \\
\hline
\end{tabular}

The source: calculated by the author on the basis of the National commission of the Securities and Stock Market data (Ukrainian enterprise reports)

Table 4

Rating estimation of the financial safety of the enterprises in the Poultry Branch Industry

\begin{tabular}{|c|c|c|c|c|c|c|c|c|c|}
\hline \multirow{2}{*}{ Enterprise } & \multicolumn{9}{|c|}{ Years } \\
\hline & 2008 & 2009 & 2010 & 2011 & 2012 & 2013 & 2014 & 2015 & 2016 \\
\hline $\begin{array}{l}\text { JSC 'Plemptakhodadgosp } \\
\text { Brovarskiy' }\end{array}$ & 5 & 4 & 3 & 4 & 4 & 2 & 2 & 2 & 2 \\
\hline JSC VasylkivskaPoultry Farm’ & 3 & 5 & 4 & 5 & 3 & 5 & 5 & 5 & 5 \\
\hline JSC 'KyivskaPoultryFarm’ & 4 & 2 & 1 & 2 & 2 & 4 & 4 & 4 & 4 \\
\hline JSC 'KrushynskyPaultry Complex' & 1 & 1 & 5 & 3 & 5 & 3 & 3 & 3 & 3 \\
\hline JSC UkrainaPoultryFarm’ & 2 & 3 & 2 & 1 & 1 & 1 & 1 & 1 & 1 \\
\hline
\end{tabular}


JSC 'KyivskaPoultryFarm'. The last place in the years of 2009, 2011, 2013-2016 was occupied by JSC Vasylkivska Poultry Farm'; in 2008 by JSC 'Plemptakhodadgosp Brovarskiy', in 2010, 2012 by JSC 'KrushynskyPaultry Complex’.

\section{Conclusions}

The scientific results of the given research allow the author to solve the scientific task, which lies in investigation the task and working out necessary provision and giving better methodological and practical steps to the mechanism of the estimation of the financial safety of the enterprise. The research of the estimation of the financial safety of the enterprise has proved that the analysis of the financial safety by the scientists is done from the position of the effective enterprise performance. But it is not taken into account the dangers, which are escorted by financial managerial performance, production fading, non-effective property status, unsteadiness. Having analyzed methodological approaches as to the estimation of the financial safety of the enterprise and clarifying a bunch of unsolved tasks, the author suggested the methodology of the analysis on the basis of the calculation of the integral indicator and taking into consideration the scientific method of the systematic analysis.

To calculate the integral indicator of the financial safety of the enterprise is important to take in to consideration the combined indicators, which reflect financial state of the enterprise like: effectiveness (ineffectiveness) of the property status, profitability (unprofitability) liquidity, pay ability (non pay ability), financial steadiness (unsteadiness), business activity (fading).

There have also been tack led the mechanism of practical calculations of the enterprise financial safety stat which is applicable in case target pursuing and giving the quantitative estimation of the safety in dynamics , comparison, having the rating estimation in a separate branch of production.

\section{References:}

Alkema, V.G. Theoretical principals in the development of the system of the economic security of the logistics units. [Electronic resource]. Retrieved from: http://ea.dgtu.donetsk.ua

Biloshkurska N.V. (2011). The resource component index formation of the economical or ganizational mechanism of the economical safety of the enterprise in Cherkassy Region, Ukraine. Notes of Chernivtsi Tradeand Economy University. Economical Sciences, - Chernivtsi. Issue 4(44): 154-158.

Bilomistna I.I. (2014). Estimation of the financial safety state on the basis of economy-mathematical modelling, Science notes of Kherson State University. - Issue 4: 28-32.

Bolbotenko, I.V. (2012). The system forming factors of the economic security of the audition activity subjects. Science notes of KROK University, Vol. 32, issue 1: 170-180.

Ganushchak T.V. (2012). The provision mechanism of the financial safety in poultry industry, Thesis: 21.04.02. K., 22 p.

Khrapkina V.V. (2010). Estimation of the level of the financial safety of the enterprise. - Chernivtsi. Issue.4(44): 191-194.

Kopytko, M.I. (2015). All sided provision with economic security of the enterprise: Theses notes.: 21.04.02. K., 478 p.

Nusinova O.V. (2011). Estimation of the financial safety of the enterprise. On the basis of owners' interests, Academical Review. - Issue2 (35): 60-64.

Petryna O.B. (2010). Methodology of the estimation of the financial safety of the enterprise., Science notes of the National timber technology university. Issue 12: 229-237.20.

Ukrainian enterprise reports [Electronic resource]. Retrieved from: http://smida.gov.ua/ (date of revision 06/10/2017).

\section{Татьяна ГАНУЩАК}

\section{ДИНАМИКА РАЗВИТИЯ ФИНАНСОВОЙ БЕЗОПАСНОСТИ ПРЕДПРИЯТИЯ КАК СОСТАВЛЯЮЩЕЙ ЭКОНОМИЧЕСКОЙ БЕЗОПАСНОСТИ ГОСУДАРСТВА}

Аннотация. Целью данной статьи является оценка эффективности финансовой безопасности предприятия. Для достижения поставленной цели необходимо было решить следующие задачи: использовать подходы к финансовой безопасности предприятия, внедрить систему анализа финансовой безопасности предприятия, дать описание интегрального показателя финансовой безопасности предприятия; оценивать и сравнивать компании в соответствии с уровнем их финансовой безопасности. Методология. Методическую основу исследования составляют общенаучные методы, а именно: методы логического обобщения, диалектический метод познания экономических явлений - для определения содержания понятий «экономическая безопасность предприятия», «финансовая безопасность предприятия»; методы группировки, анализа использовались для оценки индикаторного состояния финансовой безопасности предприятий птицеводства; 
Vol. 3, No. 4, 2017

графический метод применялся для сравнения интегральной оценки финансовой безопасности предприятия; методы синтеза, индукции, дедукции, метод экспертных оценок использовались для расчета и внедрения интегрального показателя финансовой безопасности предприятий птицеводства; метод корреляционного анализа применялся для определения весовых коэффициентов комплексных показателей имущественного положения, деловой активности, рентабельности, финансовой устойчивости, платежеспособности. Приоритетность использования того или иного метода определялась конкретной задачей и поставленной целью. Результаты исследования показали широкий набор способов финансовой безопасности предприятий как компонент экономической безопасности государства. Существует оценка финансовой безопасности предприятия на основе расчетов интегрального показателя, в том числе комбинированных показателей прибыльности (убыточности), платежеспособности или ее отсутствия, деловой активности, финансовой устойчивости (неустойчивости), эффективности (неэффективности) состояния собственности. Наконец, данная работа представляет собой систему финансовой безопасности предприятий, в том числе агентов финансовой безопасности и подсистем управления для обеспечения финансовой безопасности предприятий. Практическая значимость. Подтверждением практического значения полученных результатов является использование методики оценки финансовой безопасности предприятий с учетом комплексных показателей рентабельности, финансовой устойчивости, деловой активности и имущественного состояния была эффективно внедрена в производственный процесс ООО «Птицефабрика Киевская». 